\title{
COLOUR TRAITS OF CHICKEN EGGS WITH DIFFERENT EGGSHELL PIGMENTATION
}

\author{
H. Lukanov ${ }^{1 *}$, A. Genchev ${ }^{1}$, A. Pavlov ${ }^{2}$ \\ ${ }^{1}$ Faculty of Agriculture, Trakia University, Stara Zagora, Bulgaria \\ ${ }^{2}$ Faculty of Veterinary Medicine, Trakia University, Stara Zagora, Bulgaria
}

\begin{abstract}
The study was carried out with 11 purebred groups of chickens at 48 weeks of age, laying eggs with white, tint, blue-green and brown shell pigmentation to investigate the colour characteristics of eggshells in the CIE $\mathrm{L}^{*} \mathrm{a}^{*} \mathrm{~b}^{*}$ colour system. On the basis of $\mathrm{L}^{*}, \mathrm{a}^{*}$ and $\mathrm{b}^{*}$ values, $\mathrm{C}^{*}$ (Chroma), Hue (the angle between $\mathrm{b}^{*}$ and $\mathrm{a}^{*}$ colour coordinates) and SCI (eggshell colour index) values were calculated. L* values decreased statistically significantly $(\mathrm{P}<0.001)$ from 92.7 in white-shelled eggs to 40.2 in dark brown eggs. Brown eggs had $\mathrm{a}^{*}$ values between 1.9 and 22.5, which increased from cream-coloured to dark brown shells. In bluegreen and tinted eggs, $\mathrm{L}^{*}$ and $\mathrm{b}^{*}$ values were similar. In blue-green eggs, the values of the $\mathrm{a}^{*}$ colour coordinate were negative. There was a substantial variation in the colour of eggs not only within the groups, but also within the breed. The shell colour index (SCI) is suitable for reliable colour identification only in brown and non-pigmented eggs. SCI values lower than 70 could be recommended as reference values for brown pigmented shells whereas SCI values over 85 - for white-shelled eggs. Spectrophotometric analysis is appropriate for use in eggs with uniform pigmentation of the shell. The Hue ${ }^{0}$ angle is not suitable for colour analysis of eggshells due to the extremely large variations and the possibility to obtain similar values but with different sign in eggs with similar colour.
\end{abstract}

Key words: chicken eggs, eggshell colour, $\mathrm{L}^{*}, \mathrm{a}^{*}, \mathrm{~b}^{*}$, shell colour index.

\section{INTRODUCTION}

The main pigments responsible for the coloration of eggs of wild and domestic birds are protoporphyrin IX, biliverdin IX and biliverdin zinc chelate (1). This was later confirmed by Kennedy and Vevers, 1976 (2), who found traces of coproporphyrin III as well. These pigments are accumulated in the surface layers of shells (3, 4). Either independently or in combination, they determine the different shell colour and the tints within the same colour range of eggs in different wild and domestic bird species. Studies in more than 100 avian species provide proofs that the only pigments in blue-shelled eggs are biliverdin IX and biliverdin zinc chelate (2). The colour of brown-shelled eggs is due to large amounts of protoporphyrin, and uroporphyrin

\footnotetext{
*Correspondence to: Hristo Lukanov, PhD student at Department of " Animal Science - monogastric and other animals", Faculty of Agriculture, Trakia University,6000 Stara Zagora, Bulgaria, e-mail: dr_lukanov@abv.bg,telephone: +359/898419751.
}

and coproporphyrin are also detected (5). Two independent studies in the Dongxiang chicken breed producing blue eggs confirmed the presence of high levels of biliverdin and low amounts of protoporphyrin in eggshells $(3,6)$. The lack of shell pigmentation yields the white colour of eggs, most popular in White Leghorns. The combination between green and brown pigments results in olive green or grey-green eggshells.

The major part of laying hens on a global scale produce white or brown to cream - coloured eggs. This is true for the most commonly used egg-laying hybrids. A relatively small part of chicken breeds laid eggs with a colour different from aforementioned ones. One group of breeds carries the $O$ allele (SLCO1B3), which determines the appearance of blue-green shell pigmentation (7). This phenomenon was reported as early as in the Middle Ages, but probably, its origins reach back to a rather earlier period. At a global scale, the variety of chicken breeds and breed groups laying blue-green 
shelled eggs is significant. Such breeds are Araucana standard and bantam, Ameraucana standard and bantam, British Araucana standard and bantam, Cream Legbar, Javanese Bantam, Schijndelaar, Rapanui/Olmec breed group, Dongxiang, Lushi, Pama, Isbar, Svrljig chicken (8). Several egg-laying strains producing eggs with blue-green shells have been created. A small group of West European breeds created by the end of $19^{\text {th }}$ and the early $20^{\text {th }}$ century are outlined with excessive protoporphyrin pigmentation resulting in dark brown shell colour - these are the Marans, Welsumer and Barnevelder breeds. In Germany and the UK, egg-laying hybrids laying dark brown eggs were created on the basis of Marans. There are also populations, lines and individuals producing eggs with violet, saturated blue colour, with rose tint of the eggshell etc. In some breeds (Marans, Bielefelder) and strains, eggshells are speckled, which is manifested with appearance of dark spots of various shape and size at the background (mainly brown).

During the last years, the world producers of brown egg-laying hybrids pay an increasing attention to eggshell colour through selection for lines producing eggs with darker brown colour. The factors influencing the shell pigmentation are numerous, but heredity is the primary one with moderate heritability $\left(\mathrm{h}^{2}=0.35-0.45\right)$. Although the eggshell colour is not directly related to egg quality, it is an important factor of market demand and closely associated to consumer attitudes (9). The great variety of hybrid combinations on the world market is the cause for the different brown colour intensity of
LUKANOV H., et al. eggs in retail markets. Not only the different hybrids, but also the individuals within the hybrid combination depending on their origin, are responsible for the individually tainted shells (10).

\section{PURPOSE}

The various pigmentation of eggshells and the exceptional variety of colour tints, especially in brown-shelled eggs, has determined the purpose of the present study: to investigate the colour features of chicken eggs with various eggshell colour in different chicken breeds.

\section{MATERIALS AND METHODS}

The study was carried out with 11 purebred groups of chickens laying eggs with white, tinted, blue-green and brown shell pigmentation (Figure 1). Two groups were representative of chickens laying white-shelled eggs - two genotypes of the White Leghorn breed. One of the breeds - Black Shumen chicken - laid eggs with tinted colour. For determination of the colour features of green-shelled eggs, two groups from the Schijndelaar and Araucana breeds were used. Six groups included representatives of chickens laying brown-shelled eggs whose spectrum included the range from cream to dark brown colour. The groups were represented by Wyandotte (cream-coloured eggs), a white mutation of Rhode Island Red breed, three Rhode Island Red strains (light brown to brown colour of eggs) and one group of black-copper Marans (dark brown eggs). All birds were 48 weeks of age and were fed compound feed according to the age category.

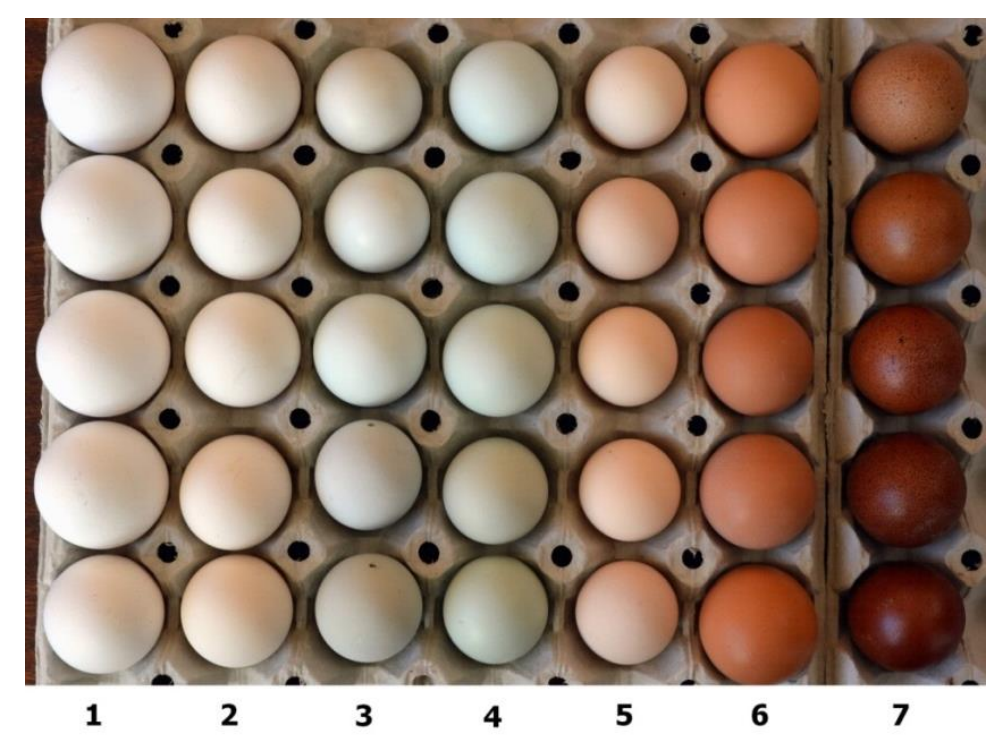

Figure 1. Color variation in different eggshell pigmentations 
Thirty eggs were collected from each group and spectral analysis was performed. The analysis of colour was done at the Poultry Breeding Unit, Department of Animal Science - Monogastric and Other Animals, Faculty of Agriculture, Trakia University, Stara Zagora. Eggshell colour was determined in the CIE L*a*b* colour system (11). For this purpose, a Konica Minolta CM-700d spectrophotometer was used. The values of $L^{*}, a^{*}$ and $b^{*}$ coordinates were determined in three zones: blunt edge, sharp edge and equatorial egg region. From $\mathrm{a}^{*}$ and $\mathrm{b}^{*}$ values, the chroma $\left(\mathrm{C}^{*}\right)$ and the angle between $\mathrm{b}^{*}$ and $\mathrm{a}^{*}\left(\mathrm{Hue}^{\mathrm{O}}\right)$ of colour were calculated (12):

$\left(\mathrm{C}^{*}\right)=\left(a *^{2}+b *^{2}\right)^{\frac{1}{2}} ;[1]$

$\left(\mathrm{h}^{\mathrm{o}}\right)=\tan \frac{b *}{a *}[2]$.

The colour index of the eggshell was determined according to the formula (9):

$(\mathrm{SCI})=L *-a *-b *[3]$,

where lower values corresponded to a darker colour.
The results were submitted to statistical analysis using classic statistical methods via the MS Excel 2003 software.

\section{RESULTS}

The analysis of colour characteristics of chicken eggs with various shell pigmentation showed that lightness $\left(\mathrm{L}^{*}\right)$ values decreased expectedly $(\mathrm{P}<0.001)$ from 92.7 in white-shelled to 40.2 in dark-brown shelled eggs (Figure 2). The variation of lightness values was the least for white eggs, from 87.3 to 98.8 for white eggs and from 80.9 to 89.9 in tinted eggs (Table 1). In these groups, the average $a^{*}$ values were close to neutral ones, whereas the values of the $b^{*}$ colour coordinate ranged between 2.2 and 10 (Figure 3). Thus, the $\mathrm{Hue}^{\mathrm{o}}$ values of white-shelled eggs varied within a broad range from 87.2 to $21.1^{\circ}$ in the negative part of the coordinate system, whereas the tinted eggs of Black Shumen hens exhibited a variation within very narrow ranges from 80.5 to $88.5^{\circ}$ in the negative and from 79 to $88.4^{\circ}$ in the positive area of the coordinate system.

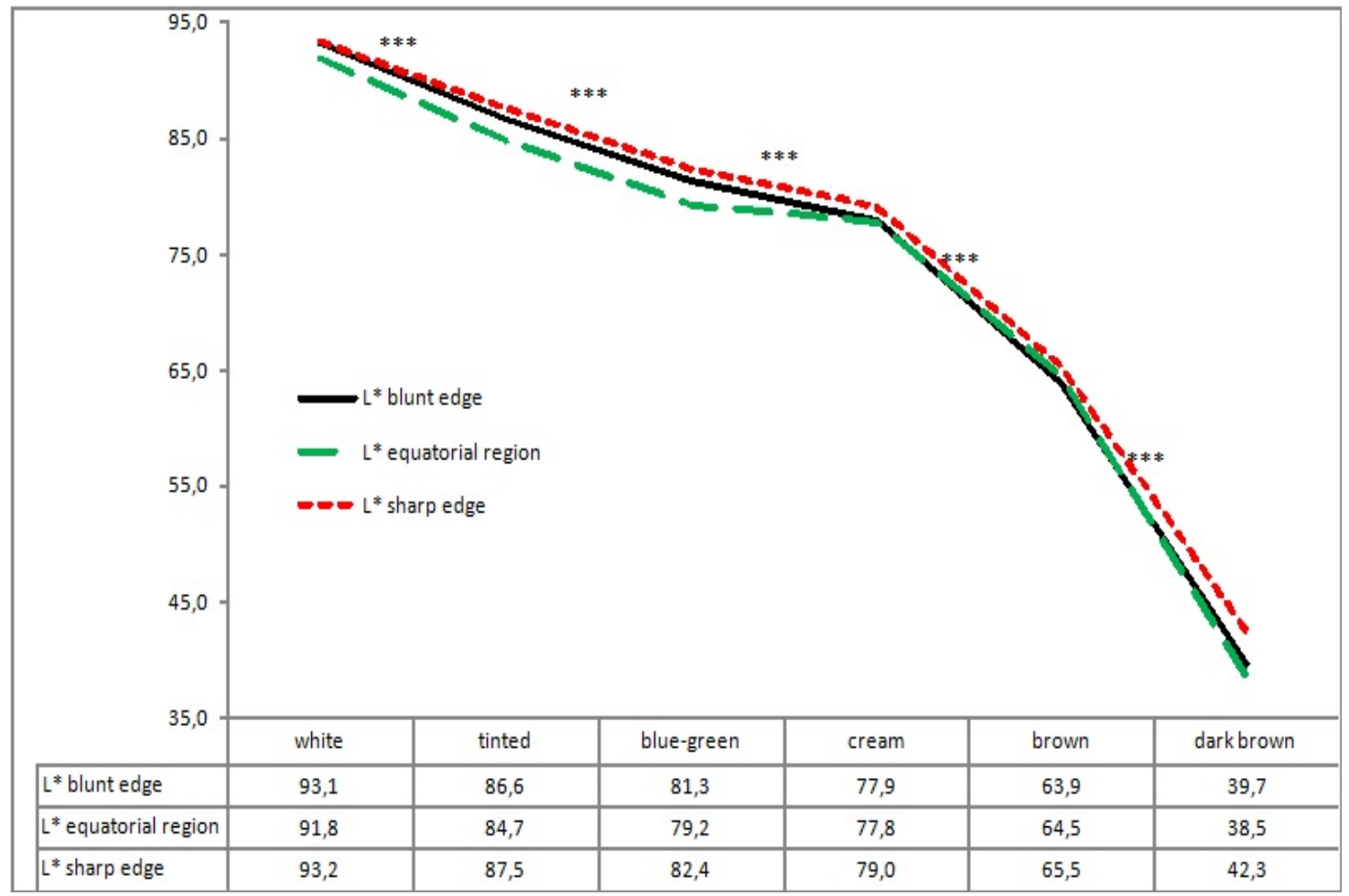

Figure 2. L* values in different zones of the eggs.

$\mathrm{L}^{*}$ variations were the greatest in brown-shelled eggs, which was anticipated taking into consideration the broad spectrum of colour tints - from cream-coloured shells of Wyandotte eggs to dark brown eggs of Marans (Figure 1, Figure 4). In this group, the $a^{*}$ coordinate varied between 1.9 and 22.5, and average values increased from cream-coloured to dark brown eggs $(\mathrm{P}<0.001)$. The $\mathrm{b}^{*}$ values were within $11.1-$ 31.3 with greater variation in dark brown eggs of Marans ( $\mathrm{VC}=18,6 \%$ ). The angle $\mathrm{Hue}^{\circ}$ in this group of eggs was in the positive part of the coordinate system within 12 and $78^{\circ}$. It should be stated that the lowest $\mathrm{Hue}^{\mathrm{o}}$ variation was in Rhode Island chickens, and the highest - in Wyandottes. 
Table 1. Color characteristics of the eggshell from different breeds of chickens.

\begin{tabular}{|c|c|c|c|c|c|c|c|c|c|c|c|c|}
\hline \multirow{2}{*}{ Chicken breeds } & \multicolumn{4}{|c|}{$\mathrm{L}^{*}$} & \multicolumn{4}{|c|}{$a^{*}$} & \multicolumn{4}{|c|}{$\mathrm{b}^{*}$} \\
\hline & $\mathrm{B} * *$ & $\mathrm{E}^{* *}$ & S** & $\min \div \max$ & $\mathrm{B} * *$ & $\mathrm{E}^{* *}$ & $\mathrm{~S} * *$ & $\min \div \max$ & $\mathrm{B} * *$ & $\mathrm{E}^{* *}$ & $\mathrm{~S} * *$ & $\min \div \max$ \\
\hline $\begin{array}{r}\text { White Leghorn (L) } \\
\text { VC, } \%\end{array}$ & $\begin{array}{c}95,46 \pm 0,51 \\
1,93\end{array}$ & $\begin{array}{c}94,91 \pm 0,29 \\
1,12 \\
\end{array}$ & $\begin{array}{c}95,55 \pm 0,38 \\
1,44\end{array}$ & $92,6 \div 98,8$ & $\begin{array}{c}-0,50 \pm 0,16 \\
117,35\end{array}$ & $\begin{array}{c}-0,51 \pm 0,09 \\
60,25\end{array}$ & $\begin{array}{c}-0,82 \pm 0,18 \\
78,48\end{array}$ & $-2,3 \div 0,3$ & $\begin{array}{c}1,06 \pm 0,24 \\
81,57\end{array}$ & $\begin{array}{c}1,01 \pm 0,21 \\
74,73\end{array}$ & $\begin{array}{c}1,28 \pm 0,22 \\
61,92\end{array}$ & $-0,5 \div 2,8$ \\
\hline $\begin{array}{r}\text { White Leghorn (TB) } \\
\text { VC, } \%\end{array}$ & $\begin{array}{c}90,80 \pm 0,19 \\
0,77\end{array}$ & $\begin{array}{c}88,61 \pm 0,18 \\
0,72\end{array}$ & $\begin{array}{c}90,81 \pm 0,39 \\
1,54\end{array}$ & $87,3 \div 93,1$ & $\begin{array}{c}-0,61 \pm 0,08 \\
48,26 \\
\end{array}$ & $\begin{array}{c}-0,52 \pm 0,06 \\
37,95 \\
\end{array}$ & $\begin{array}{c}-0,60 \pm 0,05 \\
30,29 \\
\end{array}$ & $-1,3 \div-0,2$ & $\begin{array}{c}3,65 \pm 0,50 \\
49,02\end{array}$ & $\begin{array}{c}3,15 \pm 0,36 \\
41,02\end{array}$ & $\begin{array}{c}2,99 \pm 0,35 \\
42,57\end{array}$ & $1,4 \div 8,2$ \\
\hline $\begin{array}{r}\text { Black Shumen } \\
\text { VC, } \%\end{array}$ & $\begin{array}{c}86,55 \pm 0,72 \\
2,98\end{array}$ & $\begin{array}{c}84,71 \pm 0,62 \\
2,62\end{array}$ & $\begin{array}{c}87,53 \pm 0,47 \\
1,95\end{array}$ & $80,9 \div 89,9$ & $\begin{array}{c}0,10 \pm 0,41 \\
1518,47\end{array}$ & $\begin{array}{c}0,37 \pm 0,33 \\
323,82\end{array}$ & $\begin{array}{c}0,23 \pm 0,33 \\
508,07\end{array}$ & $-1,7 \div 3,0$ & $\begin{array}{c}11,91 \pm 1,02 \\
30,96\end{array}$ & $\begin{array}{c}9,68 \pm 0,81 \\
30,33\end{array}$ & $\begin{array}{c}8,52 \pm 0,90 \\
38,29\end{array}$ & $4,4 \div 17,8$ \\
\hline \begin{tabular}{|ll} 
Schijndelaar & \\
& $\mathrm{VC}, \%$ \\
\end{tabular} & $\begin{array}{c}83,06 \pm 0,82 \\
3,56 \\
\end{array}$ & $\begin{array}{c}80,63 \pm 0,68 \\
3,06 \\
\end{array}$ & $\begin{array}{c}84,63 \pm 0,71 \\
3,03 \\
\end{array}$ & $75,5 \div 88,9$ & $\begin{array}{c}-2,69 \pm 0,33 \\
43,89 \\
\end{array}$ & $\begin{array}{c}-2,93 \pm 0,29 \\
35,25 \\
\end{array}$ & $\begin{array}{c}-3,04 \pm 0,25 \\
29,56 \\
\end{array}$ & $-4,6 \div-0,8$ & $\begin{array}{c}6,79 \pm 0,85 \\
45,12 \\
\end{array}$ & $\begin{array}{c}6,54 \pm 0,72 \\
39,92 \\
\end{array}$ & $\begin{array}{c}6,98 \pm 0,79 \\
40,93\end{array}$ & $3,7 \div 12,7$ \\
\hline Araucana & $\begin{array}{c}79,53 \pm 1,36 \\
6,17 \\
\end{array}$ & $\begin{array}{c}77,84 \pm 1,05 \\
4,86 \\
\end{array}$ & $\begin{array}{c}80,10 \pm 1,35 \\
6,07 \\
\end{array}$ & $69,6 \div 85,9$ & $\begin{array}{c}-5,67 \pm 0,30 \\
19,36 \\
\end{array}$ & $\begin{array}{c}-5,64 \pm 0,32 \\
20,37 \\
\end{array}$ & $\begin{array}{c}-6,04 \pm 0,34 \\
20,48 \\
\end{array}$ & $-8,2 \div-3,0$ & $\begin{array}{c}11,38 \pm 0,83 \\
26,23\end{array}$ & $\begin{array}{c}10,39 \pm 0,88 \\
30,59\end{array}$ & $\begin{array}{c}10,63 \pm 0,94 \\
31,79 \\
\end{array}$ & $4,5 \div 16,8$ \\
\hline Wyandotte & $\begin{array}{c}77,86 \pm 0,75 \\
3,46\end{array}$ & $\begin{array}{c}77,79 \pm 0,54 \\
2,48\end{array}$ & $\begin{array}{c}79,01 \pm 0,72 \\
3,27\end{array}$ & $71,7 \div 83,6$ & $\begin{array}{c}4,21 \pm 0,52 \\
44,73\end{array}$ & $\begin{array}{c}4,33 \pm 0,34 \\
28,42\end{array}$ & $\begin{array}{c}5,12 \pm 0,41 \\
28,93\end{array}$ & $1,9 \div 8,8$ & $\begin{array}{c}15,22 \pm 0,9 \\
21,25\end{array}$ & $\begin{array}{c}15,85 \pm 0,68 \\
15,40\end{array}$ & $\begin{array}{c}15,85 \pm 0,78 \\
17,71\end{array}$ & $11,1 \div 23,3$ \\
\hline RIR (1) & $\begin{array}{c}73,75 \pm 0,75 \\
3,65 \\
\end{array}$ & $\begin{array}{c}72,89 \pm 0,62 \\
3,08 \\
\end{array}$ & $\begin{array}{c}75,90 \pm 0,95 \\
4,53 \\
\end{array}$ & $68,0 \div 79,8$ & $\begin{array}{c}13,06 \pm 0,57 \\
15,67 \\
\end{array}$ & $\begin{array}{c}12,57 \pm 0,55 \\
15,68 \\
\end{array}$ & $\begin{array}{c}12,64 \pm 0,61 \\
17,50 \\
\end{array}$ & $8,6 \div 16,4$ & $\begin{array}{c}24,34 \pm 0,82 \\
12,07 \\
\end{array}$ & $\begin{array}{c}23,59 \pm 0,71 \\
10,83 \\
\end{array}$ & $\begin{array}{c}23,52 \pm 0,65 \\
9,95\end{array}$ & $18,7 \div 28,6$ \\
\hline RIW (D) & $\begin{array}{c}68,12 \pm 1,07 \\
5,64 \\
\end{array}$ & $\begin{array}{c}68,62 \pm 0,85 \\
4,48 \\
\end{array}$ & $\begin{array}{c}71,73 \pm 0,70 \\
3,54 \\
\end{array}$ & $63 \div 76,7$ & $\begin{array}{c}15,07 \pm 0,78 \\
18,73 \\
\end{array}$ & $\begin{array}{c}13,83 \pm 0,81 \\
21,24 \\
\end{array}$ & $\begin{array}{c}14,00 \pm 0,80 \\
20,67 \\
\end{array}$ & $7,8 \div 18,6$ & $\begin{array}{c}27,90 \pm 0,78 \\
10,11 \\
\end{array}$ & $\begin{array}{c}25,61 \pm 0,96 \\
13,51 \\
\end{array}$ & $\begin{array}{c}26,40 \pm 0,72 \\
9,79\end{array}$ & $17,7 \div 31,3$ \\
\hline RIR (2) & $\begin{array}{c}56,66 \pm 0,88 \\
5,60\end{array}$ & $\begin{array}{c}58,23 \pm 0,67 \\
4,13\end{array}$ & $\begin{array}{c}58,25 \pm 0,70 \\
4,34\end{array}$ & $51,1 \div 61,1$ & $\begin{array}{c}16,51 \pm 0,34 \\
7,43\end{array}$ & $\begin{array}{c}15,21 \pm 0,51 \\
11,98\end{array}$ & $\begin{array}{c}17,53 \pm 0,23 \\
4,69\end{array}$ & $12,0 \div 19,8$ & $\begin{array}{c}27,13 \pm 0,66 \\
8,81\end{array}$ & $\begin{array}{c}24,40 \pm 1,21 \\
17,91\end{array}$ & $\begin{array}{c}27,84 \pm 0,68 \\
8,74\end{array}$ & $17,0 \div 31,2$ \\
\hline RIR (3) & $\begin{array}{c}56,90 \pm 0,99 \\
6,28\end{array}$ & $\begin{array}{c}58,41 \pm 0,84 \\
5,16\end{array}$ & $\begin{array}{c}55,95 \pm 1,13 \\
7,31\end{array}$ & $53,1 \div 69,1$ & $\begin{array}{c}16,35 \pm 0,48 \\
10,61\end{array}$ & $\begin{array}{c}14,92 \pm 0,49 \\
11,91\end{array}$ & $\begin{array}{c}17,63 \pm 0,69 \\
14,17\end{array}$ & $10,8 \div 19,8$ & $\begin{array}{c}27,73 \pm 0,50 \\
6,48\end{array}$ & $\begin{array}{c}21,95 \pm 0,66 \\
10,81\end{array}$ & $\begin{array}{c}26,99 \pm 0,88 \\
11,82\end{array}$ & $17,3 \div 30,8$ \\
\hline Marans & $\begin{array}{c}39,69 \pm 1,09 \\
12,00\end{array}$ & $\begin{array}{c}38,47 \pm 1,07 \\
12,14\end{array}$ & $\begin{array}{c}42,34 \pm 1,60 \\
16,50\end{array}$ & $31,7 \div 54,9$ & $\begin{array}{c}18,25 \pm 0,64 \\
15,21\end{array}$ & $\begin{array}{c}19,16 \pm 0,60 \\
13,64\end{array}$ & $\begin{array}{c}20,30 \pm 0,34 \\
7,39\end{array}$ & $13,2 \div 22,5$ & $\begin{array}{c}20,26 \pm 0,82 \\
17,60\end{array}$ & $\begin{array}{c}20,50 \pm 0,80 \\
16,93\end{array}$ & $\begin{array}{c}22,18 \pm 1,04 \\
20,36\end{array}$ & $13,5 \div 30,3$ \\
\hline
\end{tabular}

Notes: ** B - blunt edge ; $\mathrm{E}$ - equatorial egg region; $\mathrm{S}$ - sharp edge.

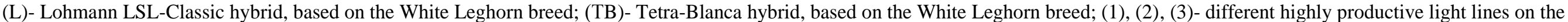
Rhode Island Red breed; (D)- highly productive white mutation on the Rhode Island Red breed. 


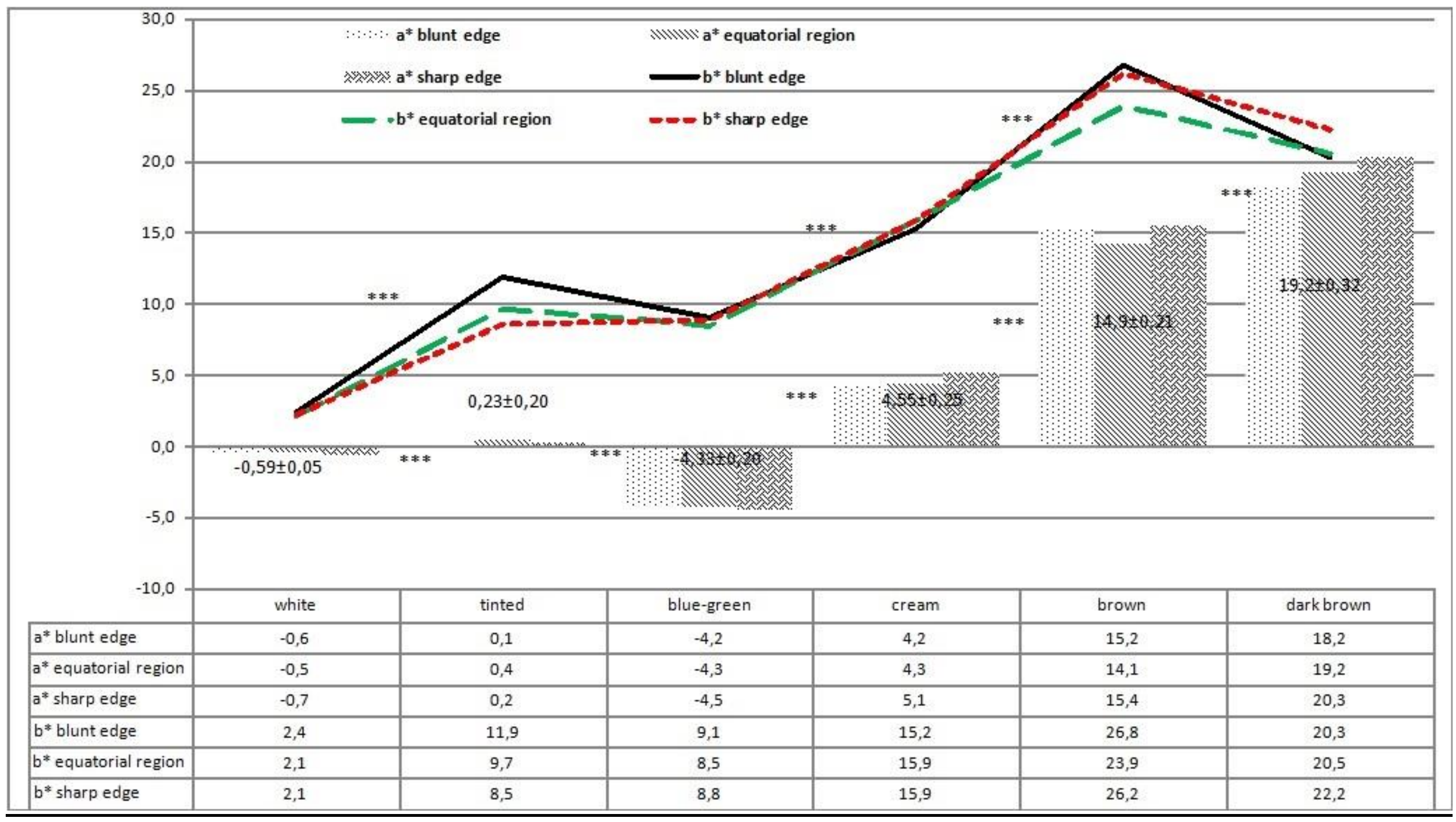

Figure 3. Value of the coordinates $\mathrm{a} *$ and $\mathrm{b} *$ in different zones of the egg. 


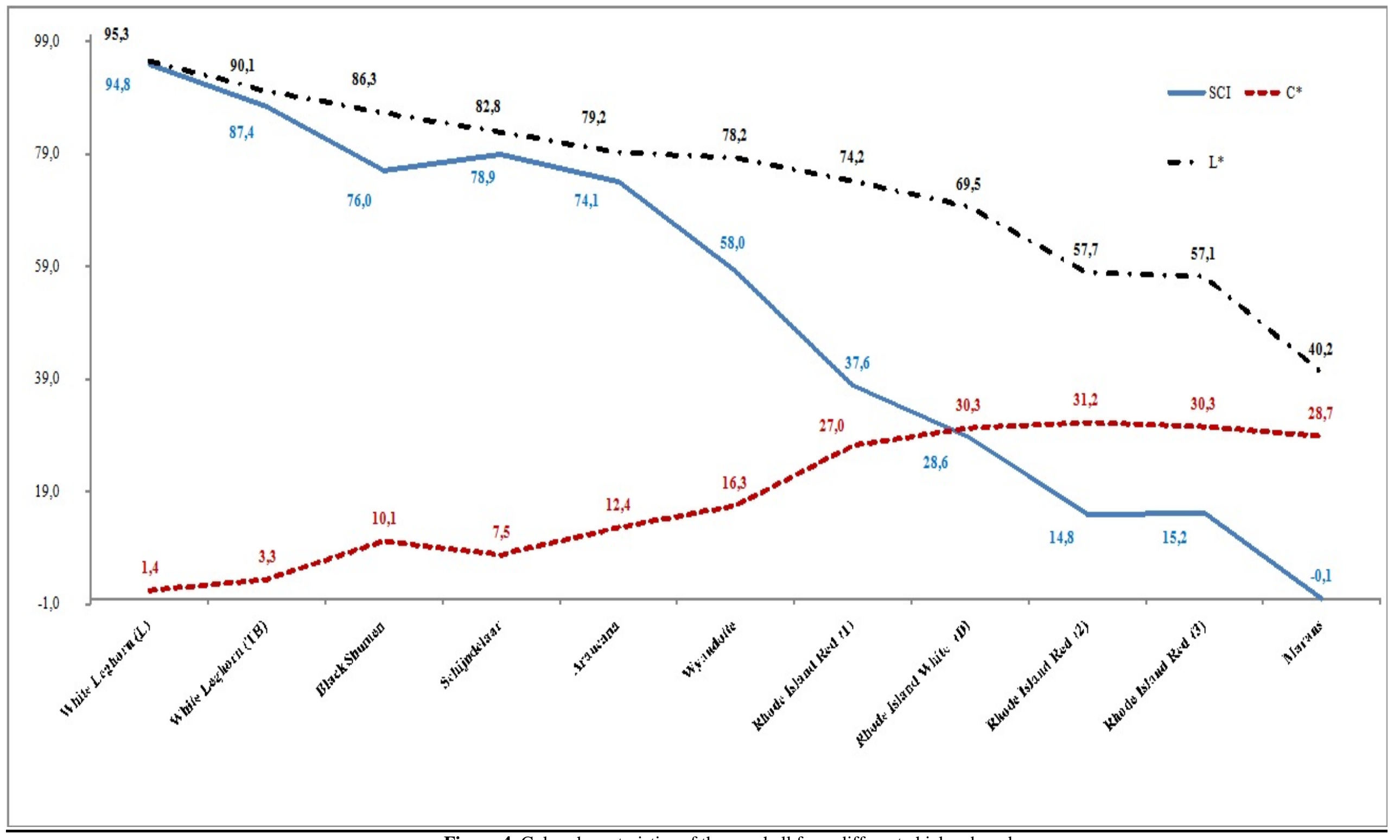

Figure 4. Color characteristics of the eggshell from different chicken breeds. 
Lightness of blue-green eggs ranged from 69.6 to 88.9; the shells of Schijndelaar eggs were slightly lighter than those of Araucana eggs (Table 1, Figure 4). The a* values were in the green spectrum (negative quadrants) and varied between -8.2 and -0.8 . The variation of the $\mathrm{b}^{*}$ coordinate was identical to that of tinted eggs: from 3.7 to $16.8(\mathrm{VC}=40.7 \%)$. The $\mathrm{Hue}^{\mathrm{o}}$ angle of blue-green eggs exhibited the highest variation from $80.5^{\circ}$ in the negative to $25.2^{\circ}$ in the positive part of the coordinate system.

The evaluation of colour characteristics of eggshells in the different studied zones (Figure 2 and 3) showed that the differences were negligible, indicating a uniform colour. In all studied groups, the shells were lighter in the sharp edge of the egg. In white and blue-green eggs, equatorial zones were the darkest, while in brown eggs - the blunt edge. With regard to the breed, average $L^{*}$ values of brown eggs were influenced by two groups of chickens, breeder lines of commercial hybrids -white mutation of the Rhode Island Red (line D) and Rhode Island Red, in which the blunt edges of eggs were darker (Table 1). In the brownshelled eggs group, Rhode Island Red strain 3 was also an exception, as sharp edges of its eggs were the darkest while the equatorial zone - the lightest.

The comparison of changes in chroma $\left(\mathrm{C}^{*}\right)$ and colour index (SCI) of eggs with different

\section{LUKANOV H., et al.} shell pigmentation with $\mathrm{L}^{*} \mathrm{a}^{*} \mathrm{~b}^{*}$ values demonstrated that $\mathrm{L}^{*}$ values were with the strongest influence on SCI - 88-98\% for white and blue-green eggs and $37-74 \%$ for brown eggs (Figure 5). With this respect it should be noted that among brown-shelled eggs, $\mathrm{L}^{*}$ had a stronger influence on SCI values - 74\% only for the cream-coloured ones. The effect of $\mathrm{L}^{*}$ for brown and dark brown eggs was less pronounced compared to the effect of the other two colour coordinates $-\mathrm{a}^{*}$ and $\mathrm{b}^{*}$, with least effect in Marans eggs (about 10\%). The determination of $\mathrm{C}^{*}$ was dominated by $\mathrm{b}^{*}$ values which constituted $73-99 \%$ of colour chroma, without any clear trend of relationship with either the breed or eggshell colour.

SCI values, similarly to $\mathrm{L}^{*}$ values, decreased $(\mathrm{P}<0.001)$ from white to dark brown eggs. The only exception was the lack of difference between SCI values in tinted eggs, whose colour is between the cream and white or bluegreen. In blue-green eggs, this resulted also from the effect of $a^{*}$ and $b^{*}$ coordinates on the index. This circumstance made impossible the utilization of SCI values as a reliable index for differentiation of pigmentation between white and tinted eggs and blue-green eggs. A proof was the overlapping of SCI values in white $(\min -83.8)$, tinted $(\max 85.7)$ and blue-green (max 89) eggs (Figure 5).

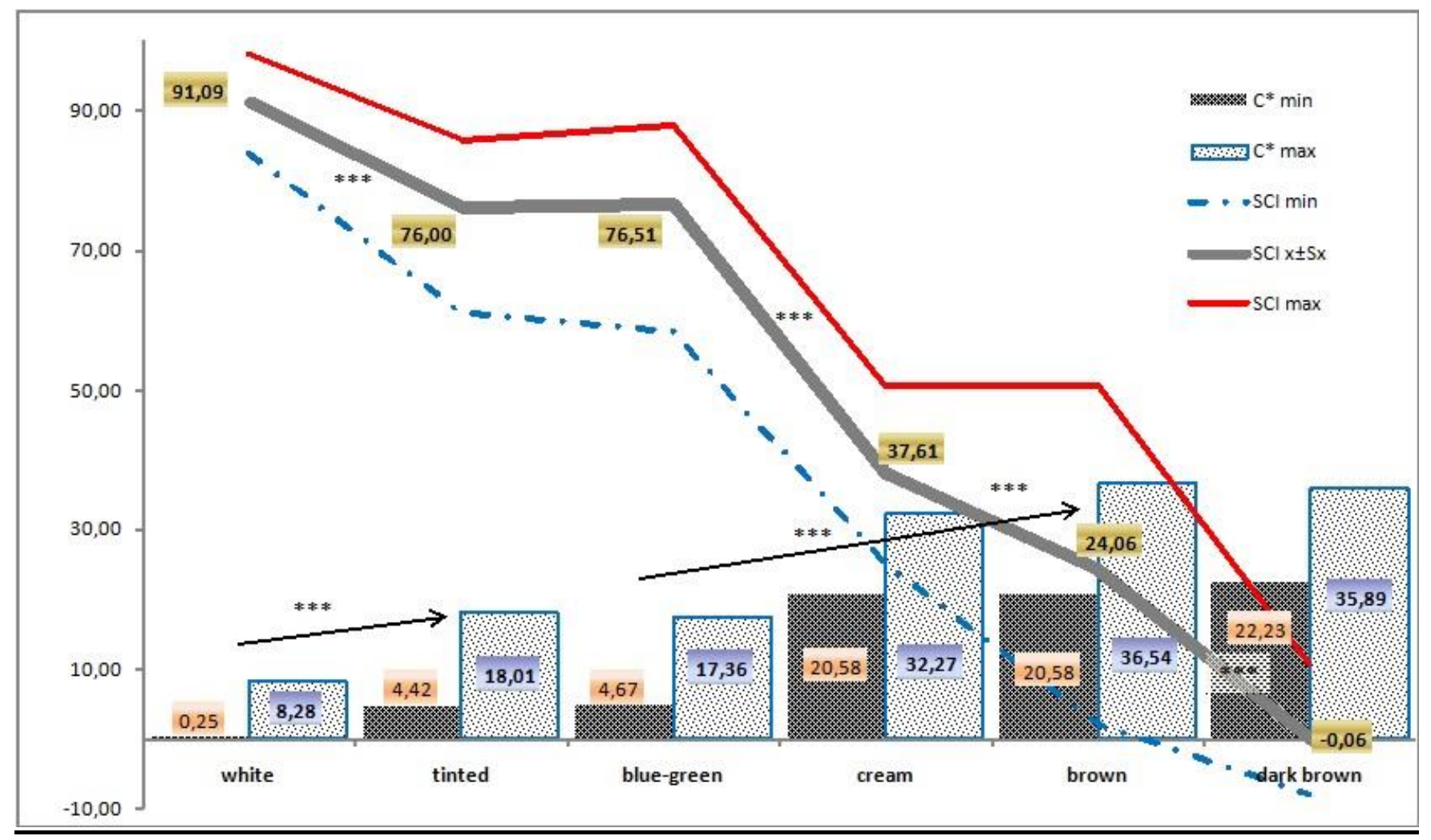

Figure 5. Chroma $\left(\mathrm{C}^{*}\right)$ and shell color index (SCI) in eggs with different pigmentation of the shell. 
In eggs with tinted and blue-green colour, there were no differences in chroma values. This could be attributed to the effect of $\mathrm{C}^{*}$ values of Schijndelaar eggs, whose shell was lighter compared to Black Shumen and Araucana eggs and with lower chroma (Figure 4). The difference between the minimum and maximum SCI values, similarly to $\mathrm{L}^{*}$, was the biggest in brown-shelled eggs - 25 times (min $2.1 \div \max 50.9$ ), and the lowest - in white eggs $-14.5 \%$ (Figure 5). The difference between minimum and maximum $\mathrm{C}^{*}$ values was the most substantial in white-shelled eggs (32 times) and relatively low and constant (36.243.7\%) in brown eggs.

\section{DISCUSSION}

Modern industrial poultry farming has set very high quality standards to egg for human consumption. A special attention is paid on eggshell quality, which is an important parameter for the economic results of the branch. Therefore, not only the thickness and strength of eggshells which determined the resistance of eggs to manipulations and transportation, but also the attractive exterior and uniform pigmentation are important. The consumer perceives egg quality depending on its subjective personal criteria, and one of them is the pure and uniform colour of eggs. That is why; pale or irregularly pigmented eggs could often be rejected by consumers (9). In the view of authors, people in most European countries prefer brown-shelled eggs whereas white eggs predominate on retail markets in the USA, Latin America and the Near East. In our opinion, this geographic distribution of used egg-laying chicken hybrids in the different parts of the world is mainly due to difference between standards of living and consumer attitudes in Europe and the other consumer societies.

The offering of eggs with different shell colours in stores has the potential to diversify consumer attitudes and revitalize the global egg commerce, as people are inclined to buy eggs with peculiar colours although their retail price could differ from that of white or brown eggs. Such a tendency was established in courtiers with notable presence of the middle class - West Europe, the USA, Japan. A similar situation is present also in China, where consumers generally prefer brown and white eggs, but recently, interest to blue-shelled eggs has emerged (10). Reported L*a*b* values of white eggs: $95.2 ;-0.8 \div-0.16 ; 0.5 \div 0.6$ (10) are very close of values established in White Leghorns (Lohmann LSL-Classic) in our study. The other studied White Leghorn genotype (Tetra Blanca) showed similar values of $\mathrm{L}^{*}$ and $\mathrm{a}^{*}$, but significantly (about 6 times) higher $b^{*}$ values. A probable explanation of this fact is the variation of colour tints within the yellow spectrum in the different White Leghorn genotypes and hybrids in our study and in cited research. On the other hand, some leading producers of egg laying hybrids, perform selection not only for production traits of parental lines, but also for eggshell colour.

In the early 1990s, In addition to subjective scoring of shell color, LOHMANN TIERZUCHT GmbH has introduced a strict control of eggshell colour in his layer hybrids in the CIE L*a*b* colour space (9). The authors outline that during the last years, a special attention is paid on the pigmentation intensity of brown eggs. In these eggs, shell colour could vary significantly between breeds and hybrids as well as among the different flocks within a breed or strain. Complying with consumers' preferences for darker eggs, leading producers of genetic material market chicken hybrids laying eggs with dark brown colour. Investigations on the change in eggshell SCI with years (2006-2011) as a result of selection in several layer hybrids (9) has shown the lowest SCI values in Lohmann Brown Classic (average for the period 13.1), and the highest - in Novobrown (19.6) and ISA Brown (18.4). The modern consumer was most satisfied with eggs whose $L^{*}$ value is close to 60, a* - about 20 and $b^{*}$ - about 30 (9), which could be accepted as a current standard in brown eggs. Through transformation of L*a*b* values into SCI, it could be concluded that most preferred brown-shelled eggs would have a SCI of about 10. These values are confirmed also by Li et al, 2006 (10), although the eggs of investigated six layer genotypes are not entirely complying with the standard $\left(\mathrm{L}^{*}\right.$ 59.4-66.9; $a^{*} 16.4-20.6$ and $b^{*} 23.8-26.9$ ). The four studied Rhode Island genotypes exhibited substantial deviations from the standard with respect to $a^{*}$ and $b^{*}$ coordinates. The $a^{*}$ values were by $18-36 \%$ lower; the $b^{*}$ values - by $11-20 \%$ lower, and SCI -by about $60 \%$ higher than the reference. These results could be attributed to the fact that studied Rhode Island strains are used for more than 40 years without strict and purposeful selection for eggshell colour intensity. Although the colour of shells differed from the most desired pigmentation, the colour of eggs of studied Rhode Island strains could be assessed as good, and with comparable characteristics with eggs of other breeds or hybrids published. The eggs of Atak-S stock layers during the first stage of the lay cycle have $\mathrm{L} * / \mathrm{a} * / \mathrm{b}^{*}=65.0 / 13.9 / 25$ (13), and eggshells of 
Lohmann Brown Classic hybrid layers at 68 weeks of age: 66.2/14.1/28.6 respectively (14). Lower values have been reported for Rhode Island Red layers - 64.9/8.1/22.4 (15).

The Black Shumen, Schijndelaar and Araucana chickens laying tinted, light blue-green and green eggs respectively, although visually different, had similar $\mathrm{C}^{*}$ and SCI values. In these breeds, the $\mathrm{L}^{*} \mathrm{a} \mathrm{b}^{*}$ values of eggs were very similar, and sometimes identical to data of $\mathrm{Li}$ et al, (2006) for two genotypes producing blue-green eggs (10). This could be explained with the still genetically "pure" populations used in the two studies and the lack of polygenic determination of the colours. Thus, it could be assumed, that the four genotypes used in both studies had a comparable background shell colour, on which the green pigment was deposited.

In brown-shelled eggs, the increasing difference between $\mathrm{L}^{*}$ and SCI allowed assuming that SCI values could be a reliable indicator for the amount of deposited porphyrin. The study has shown that SCI values $<70$ could be accepted as reference values for porphyrin deposition in the eggshell. It was also found out that SCI of dark brown eggs was <10, and that in Marans, SCI could be negative. The utilization of the shell colour index (SCI) is a very convenient and easy means for quantitation of this exterior trait. A main drawback is the overlapping values in some tints of brown and white eggs with bluegreen eggs. The eggs in this study demonstrated overlapping of average SCI of green and in tinted eggs. This flaw could be corrected by introduction of a negative coefficient $(-1)$ only for eggs with biliverdin pigmentation (blue-green and green colour), which would largely ignore this concurrence. Hence, SCI could be interpreted as a universal index for evaluation of eggs with various shell pigmentation.

\section{CONCLUSION}

There was a substantial variation in the colour of eggs not only within the groups, but also within the breed. The lowest variation of lightness was established in white and tinted eggs, as well as in blue-green Schijndelaar eggs, whose background colour was also tinted. Eggs with dark brown shells exhibited the highest variation of the trait.

The shell colour index (SCI) is suitable for reliable and unmistakable colour identification only in brown and non-pigmented eggs. SCI values lower than 70 could be recommended as reference values for brown pigmented shells
LUKANOV H., et al. whereas SCI values over 85 - for white-shelled eggs.

Spectrophotometric analysis is appropriate for use in eggs with uniform pigmentation of the shell. The $\mathrm{Hue}^{\mathrm{o}}$ angle is not suitable for colour analysis of eggshells due to the extremely large variations and the possibility to obtain similar values but with different sign in eggs with similar colour.

\section{RECOMMENDATION}

In strains producing brown eggs and "exotic" hybrids laying coloured eggs, a simpler method for eggshell colour evaluation should be sought for implementation and use in the practice. With this respect, an instrumental method based directly on the determination of the SCI could be successfully used.

\section{REFERENCES}

1. Poole, H.K., Egg shell pigmentation of Japanese quail: Genetic control of the white egg trait. Journal of Heredity, 55 (3): 136138, 1964.

2. Kennedy, G.Y. and Vevers, H.G., A survey of avian eggshell pigments. Comparative Biochemistry and Physiology, Part B: Comparative Biochemistry, 55 (1): 117123, 1976.

3. Zhao, R., Xu, G.Y., Liu, Z.Z., Li, J.Y., and Yang, N., A Study on Eggshell Pigmentation: Biliverdin in Blue-Shelled Chickens. Poultry Science, 85 (3): 546-549, 2006.

4. Wang, X.T., Deng, X.M., Zhao, C.J., Li, J.Y., Xu, G.Y., Lian, L.S. and $\mathrm{Wu}$, C.X., Study of the Deposition Process of Eggshell pigments Using an Improved Dissolution Method. Poultry Science, 86(10): 22362238, 2007.

5. Belorechkov, D., Tsvyat na yaychnata cherupka i okoloushkite pri kokoshkite. Ptitsevadstvo, 2:12-18, 2014. BG.

6. Wang, X.T., Zhao, C.J., Li, J.Y., Xu, G.Y., Lian, L.S., Wu, C.X. and Deng, X.M., Comparison of the total amount of eggshell pigments in Dongxiang brown-shelled eggs and Dongxiang blue-shelled eggs. Poultry Science, 88:1735-1739, 2009.

7. Wang, Z., Qu, L., Yao, J., Yang, X., Li, G., Zhang, Y., Li, J., Wang, X., Bai, J., Xu, G., Deng, X., Yang, N. and Wu, C., An EAVHP Insertion in 5' Flanking Region of SLCO1B3 Causes Blue Eggshell in the Chicken. PLoS Genet 9(1): e1003183, 2013. doi:10.1371/journal.pgen.1003183. (http://www.plosgenetics.org/article/info\%3 Adoi\%2F10.1371\%2Fjournal.pgen.100318 3) 16 October, 2013, date last accessed. 
8. Lukanov, H., Blue-green coloured eggs in Gallus gallus domesticus. Agricultural Science and Tehnology, 6(1): 3-10, 2014.

9. Cavero, D., Schmutz, M., Icken W. and Preisinger, R., Attractive Eggshell Color as a Breeding Goal. Lohmann Information, 47 (2): 15-21, 2012.

10.Li, X.Y., Xu, G.Y., Hou, Z.C., Zhao, R. and Yang, N., Variation of eggshell colour in different egg-type chickens. Archiv Fur Geflugelkunde, 70 (6): 278-282, 2006.

11.CIE, Colorimetry. 2nd edition. CIE Publication. No.15.2. Commission Internationale de I'Eclairage. Vienna, 1986.

12.Petracci, M. and Baeza, E., Harmonization of methodology of assessment of poultry meat quality features. 2009 . ( www.wps a.com/downloads / WPSA _ WG _ Meat

\section{LUKANOV H., et al.} Quality _ Harmonization ). 16 February, 2010, date last accessed.

13. Yildirim, A., Şekeroğlu, A., Eleroğlu, H., Şen, M.I., and Duman, M., Effects of Korean ginseng (Panax ginseng CA Meyer) root extract on egg production performance and egg quality of laying hens. South African Journal of Animal Science, 43 (2): 194-207, 2013.

14.Aygun, A., Effects of force molting on eggshell colour, egg production and quality traits in laying hens. Revue de Médecine Vétérinaire, 2: 46-51, 2013.

15.Durmuş, I., Kamanli, S., Demirtaş, Ş.E. and Demir, S., The egg quality characteristics of Barred Rock-1, Rhode Island Red-2 and Colombian. Lalahan Hayvancılık Araştırma Enstitüsü Dergisi, 50(1): 33-39, 2010. 